\title{
Parents' Role in Maintaining and Shifting Kinship Term in Vernacular Language: The Case of Intermarriage Parents in Langsa
}

\section{Maria Ulfa and Chairuddin}

Faculty of Education, Samudra University, Langsa, Aceh, Indonesia

\section{Abstract}

This study deals with parent's role in shifting and maintaining kinship term in vernacular language. It employs a case study in qualitative research design. This study aims to describe the roles of parents in maintaining and shifting kinship terms in vernacular language. The subjects were 20 children of intermarriage family; the ages range between $15-26$ years old. The instruments used in this study were questionnaire and interview. The analysis was done through interactive Model of Miles \& Huberman

Corresponding Author: Maria Ulfa

mariaulfa.fkip@unsam.ac.id

Received: 13 March 2018

Accepted: 10 April 2018

Published: 19 April 2018

Publishing services provided by Knowledge

(c) Maria Ulfa and

Chairuddin. This article is

distributed under the terms of

the Creative Commons

Attribution License, which

permits unrestricted use and

redistribution provided that the original author and source are credited.

Selection and Peer-review under the responsibility of the AICLL Conference Committee.

\section{G OPEN ACCESS} (1984). The theory of Holmes (2013) was applied in this research. The finding showed that there were fourteen respondents or $70 \%$ maintain the kinship terms and there were six respondents (30\%) shifted the kinship terms. From fourteen respondents, there were eleven children or $55 \%$ of children influenced by parents in maintaining kinship term in Aceh language and there were three children or $15 \%$ of children influenced by parents in shifting kinship terms in Aceh language. There were six or $30 \%$ of children not influenced by parents in maintaining or shifting kinship terms in Aceh language.

Keywords: Parents Role, language maintenance and shift, Vernacular Language, Intermarriage Parents

\section{Introduction}

The shift of language begins in family domain. Family is the crucial part of the language development, and home domain represents the last defense against the influence of the language of the majority language in society. The language to be extinction will not happen if the language user can keep maintaining the language. Language maintenance refers to the continuing use of the indigenous language in a majority language contact. Mesrthri (1999: 42) defines language maintenance as the continuing use of a language in the face of competition from a regionally and socially powerful or numerically stronger language. 
Indonesia is one of the countries that has lots of varieties of ethnics, cultures and varieties of vernacular languages spread all over Indonesia. The varieties of ethnics group also spread in Langsa city. Langsa is a developing city that locates in Aceh province. Because of those varieties, two kinds of social interaction develop in Langsa. Interaction between the same ethnic or intra ethnic and interaction between different ethnic or interethnic happen in Langsa. The interaction between interethnic groups in Langsa potentially occur marriage between different ethnics. It is so called as intermarriage. Marriage between different ethnics group which has different language and culture is not as easiest as marriage with the same ethnic which has lots of things in common. It needs to assimilate one culture with another culture. The cultural assimilation, more commonly referred to acculturation, is the "process of change toward greater cultural similarity brought about by contact between two or more groups [8]. The cultural assimilation influences to the language use in family. According to Crsytal (2003), when one culture assimilates to another culture, the sequence of events affecting the endangered language seems to be everywhere. For example, the phenomenon in small area in Langsa city can be the representation of the attitude of teenagers itself in using their vernacular language. The phenomenon of language shift and language maintenance also occurs in Aceh language. Aceh language is the primary communication tool among Aceh language users. This language is used in all aspects of the lives and livelihoods of Acehnese as their mother tongue. This language serves as a means of communication within the family, daily life, religion, civilization, education and teaching, government, commerce, greetings between members of one family and another family and culture.

Related to the phenomenon and theory that occurs in Acehnese family, researchers need to do more deeply research about the parent's role in shifting and maintaining a vernacular language in third generation and how the way they used the language.

\section{Literature Review}

Language shift and language maintenance are like two sides of coin. Language maintenance is a situation in which the language maintains its vitality, even under pressure (Batibo, 2005:102). On the contrary, if one does not keep maintain the language, it is possible that language shift takes place. Language maintenance and Language shift are parts of language planning, which most clearly illustrate as the full complexity of societal phenomena. Language planning refers to deliberate efforts to influence the behavior of others with respect to the acquisition, structure, or functional allocation of their codes. Jernudd \& Dass Gupta (in Fishman, 1972: 186) state that the study of 
language planning is the study of organized efforts to find solution to societal language problems. One of the language problems is language shift and the solution of societal problem is language maintenance.

\section{Kinship Term}

In addressing terms in Acehnese, society is divided into four terms, namely: kinship terms, customs terms, religious term, and office terms. Kinship terms include the relationship by blood or marriage. In this study the researchers focus on the use of kinship terms in Aceh language. There are more than thirty kinds of Kinship Term in Aceh language as stated below:

\section{Research Method}

This study is a case study research design. According to Bogdan \& Biklen (1992: 62) the case study is a detailed examination of one setting or a single subject, a single depository of documents or one particular even.

\subsection{Respondent}

The subjects in this study were twenty children from Acehnese family in Langsa. (as third generation) and age of the subjects were about 15-25 years old.

\subsection{Instrument}

The instruments of this research were observation, questionnaire and interview.

\subsection{Procedure}

Data were collected by observation, questionnaire and in-depth interview to children in age 15-26 years old. The steps are:

1. The researcher had prepared and clarified the questions to find a deep answer from the informant by using the informant's answer in the first question.

2. Then, the researcher transcribed the data from the interview.

3. Finally, the researcher analyzed the data from the questionnaire and from transcribes the interview data. 
TABLE 1: Kinship terms in Aceh language.

\begin{tabular}{|c|c|c|}
\hline No & Using & Kinship terms \\
\hline 1 & Son & Gam, Agam, amponi, Said \\
\hline 2 & Daughter & Nong, Inong \\
\hline 3 & Grandchildren (boys/girls) & Name, Nyak+name, Nyak+agam/inong \\
\hline 4 & Younger brother/youngest brother & Nome, Adek, dek+ name, dek gam \\
\hline 5 & Younger sister/youngest sister & Dek, dek + name \\
\hline 6 & Elder sister & kak, kak +name, cutda, cutti, cupo \\
\hline 7 & Elder Brother & bang, bang +name, cut bang \\
\hline 8 & Wife & $\begin{array}{l}\text { ma siinong/ siogam, adek ma+ name of } \\
\text { eldest child, only name, gata }\end{array}$ \\
\hline 9 & Husband & $\begin{array}{l}\text { Abang, cutbang, bang+name, yahsi gam, yah } \\
\text { siinong, bapakjih }\end{array}$ \\
\hline 10 & Husband of elder sister/brother & $\begin{array}{l}\text { bang, bang+ name, polem/kak, kak +name, } \\
\text { cut da }\end{array}$ \\
\hline 11 & $\begin{array}{l}\text { Husband of younger or youngest } \\
\text { sister/brother }\end{array}$ & Dek, dek + name \\
\hline 12 & Wife of elder sister/brother & kak, kak+name \\
\hline 13 & Wife of younger or youngest sister/brother & Name \\
\hline 14 & Elder sister of wife/husband & $\begin{array}{l}\text { kak, kak +name, cuda, cutkak/bang, } \\
\text { bang+name, cut bang }\end{array}$ \\
\hline 15 & Younger(est) of wife/husband & Dek, dek + name, only name \\
\hline 16 & Mother of mother & makha, nenek, maknek, misyik, nek \\
\hline 17 & Father of Mother & Nektu, syik, abusyik, yahnek \\
\hline 18 & Biological Mother & Ma(k), Um(mi), Nyak, Bunda \\
\hline 19 & Biological Father & Ayah, Abu, Abi, Abah, Bapak \\
\hline 20 & Younger/youngest brother of father & yah cut, yahbit, yahcek, yahngah, apa, \\
\hline 21 & Elder brother of father & abuwa, pakwo \\
\hline 22 & Elder sister of father & ma cut, teh, mak lot \\
\hline 23 & Younger/youngest sister of father & ma cut, teh, cut ma \\
\hline 24 & Elder sister of Mother & mawa, Miwa, Nyakwa \\
\hline 25 & Younger/youngest sister of Mother & ma(k) cek, cecek, cek +name \\
\hline 26 & Elder brother of Mother & Ayah wa, abuwa, wa \\
\hline 27 & Younger /youngest brother of mother & yah cut, Pa cut, apa, pakcek, cek +name \\
\hline 28 & Mother of father & Nek, Misyik \\
\hline 29 & Father of father & nek, nektu, yahnek, Abunek, Abu \\
\hline 30 & Name self & Lon, long, kee, Ulon, ulontuon, name of self \\
\hline
\end{tabular}

\subsection{Data analysis}

The data were done through interactive Model of Miles \& Huberman (1984: 23). The data from questioner and interview were analysed through the following two procedures: 
The first procedure of data collection is questioner. The data from the questionnaire is analyzed through these following steps:

1. Data reduction: identification the factors that influencing language Maintenance of addressing term in Acehnese young generation intermarriage family and the patterns of the language use.

2. Data Display.

3. Verification and conclusion.

Next, the second procedure is getting the data from interview through the following steps

1. Transcribe the data from audio recorder

2. Classify Data transcription

3. Verify the pattern of language maintenance in intermarriage family

4. Conclude the reasons of the Acehnese children in Langsa.

\section{Discussion}

Parents have very big role toward children language acquisition. According to Holmes (2003) in addressing or referring member in family the terminology that language can identify the social background of the family. Parent's education may describe social background of family. The table below showed parents education background in intermarriage family in Langsa.

Educational level of parents will influence the development of children. Scotton (2006: 201) stated that the social class and education level of parents often play decisive role. In some families of middle class, children seldom show formal respects and deference to their elder and when they grow up, they replace the child - parent relationship with one of equals or near equals.

Parents take important roles in maintaining the kinship terms as well as shifting them, below is a chart of the parents' role that influence the maintenance and shift of kinship terms in intermarriage family which is analyzed from twenty respondents.

The figure above shows that there were fifty five percent of children influenced by parents in maintaining the kinship terms. There were ten percents of children influenced by parents in shifting the kinship terms. And there were thirteen percent not influenced by parents in maintaining or shifting the kinship terms. There were fifty 
TABLE 2: Parent's Education Background.

\begin{tabular}{|c|c|c|c|c|c|c|c|}
\hline & & \multicolumn{2}{|c|}{ Parents tribe } & \multicolumn{2}{|c|}{ Language Use } & \multicolumn{2}{|c|}{ Parents Education } \\
\hline & & Father & Mother & Father & Mother & Father & Mother \\
\hline & $\mathrm{R}_{3}$ & Acehnese & Batak & $\mathrm{AL}$ & $\mathrm{BL}+\mathrm{IL}$ & $D_{3}$ & $D_{3}$ \\
\hline & R8 & Acehnese & Javanese & $A L$ & $J \mathrm{~L}+\mathrm{IL}$ & SLTP & SLTP \\
\hline & R10 & Acehnese & $\begin{array}{c}\text { Batak } \\
\text { Mandailing }\end{array}$ & $A L$ & $\mathrm{BL}+\mathrm{IL}$ & SMP & SMEA \\
\hline Maintain & $\mathrm{R} 13$ & Padangnese & Acehnese & $A L$ & AL & $\mathrm{S}_{1}$ & SMP \\
\hline \multirow[t]{4}{*}{ Completely } & R16 & Padangnese & Acehnese & IL & $\mathrm{AL}$ & S1 & S1 \\
\hline & R17 & Bataknese & Acehnese & $\mathrm{BL}$ & $\mathrm{AL}$ & SMA & $D_{3}$ \\
\hline & R18 & Javanese & Acehnese & AL & $\mathrm{AL}$ & SD & SD \\
\hline & R1 & Acehnese & Javanese & $A L+I L$ & $J \mathrm{~L}+\mathrm{IL}$ & SMA & SMA \\
\hline Maintain & $\mathrm{R}_{5}$ & Acehnese & Javanese & $A L+I L$ & $J \mathrm{~L}+\mathrm{IL}$ & $S_{1}$ & $S_{1}$ \\
\hline \multirow[t]{7}{*}{ Partly } & R6 & Acehnese & Javanese & $A L+I L$ & $J \mathrm{~L}+\mathrm{IL}$ & S1 & SMA \\
\hline & R7 & Acehnese & Malay & $A L+I L$ & IL & SMA & S1 \\
\hline & R9 & Acehnese & Padangnese & $A L+I L$ & $\mathrm{IL}$ & SMA & SMA \\
\hline & R19 & Malay & Acehnese & $P L+J L$ & $A L+I L$ & SD & SMA \\
\hline & R20 & Malay & Acehnese & $P L+I L$ & $A L+I L$ & SD & SMP \\
\hline & $\mathrm{R}_{2}$ & Acehnese & Javanese & IL & $J \mathrm{~L}+\mathrm{IL}$ & SD & SD \\
\hline & $\mathrm{R}_{4}$ & Acehnese & Javanese & $J \mathrm{~L}+\mathrm{IL}$ & $J \mathrm{~L}+\mathrm{IL}$ & SMA & SD \\
\hline \multirow[t]{4}{*}{ Shift } & R11 & Padangnese & Acehnese & $P L+I L$ & IL & $S_{1}$ & $S_{1}$ \\
\hline & $\mathrm{R} 12$ & Javanese & Acehnese & $J \mathrm{~L}+\mathrm{IL}$ & $J \mathrm{~L}+\mathrm{IL}$ & SMP & SMP \\
\hline & R14 & Padangnese & Acehnese & $P L+I L$ & $P L+I L$ & $\mathrm{~S}_{1}$ & SMEA \\
\hline & R15 & Padangnese & Acehnese & $P L+I L$ & IL & SMA & S1 \\
\hline
\end{tabular}

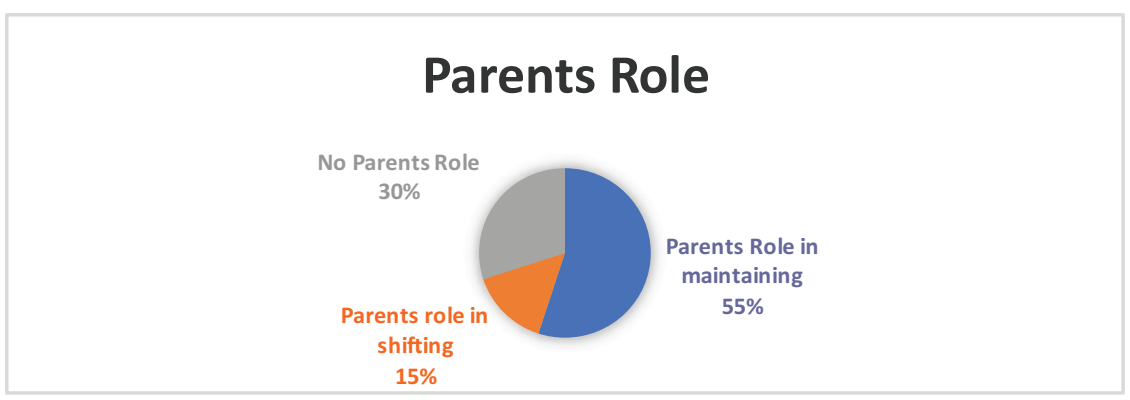

Figure 1: Parents Role.

five percent of children who were influenced by parents' role above were divided into the role of parents in Acehnese fathers and the role of parents in Acehnese mothers, the table of percentage of children from AF-NAM and AM-NAF as shown below:

The above table shows that there were $25 \%$ of children whose Acehnese father and Non-Acehnese mother wereinfluenced by Acehnese father in maintaining the kinship terms completely and partly. It was shown by five respondents below: 
TABLE 3: The role of AF-NAM and AM-NAF in maintaining the kinship terms in completely and partly in Aceh language.

\begin{tabular}{|c|c|c|c|c|c|c|}
\hline \multirow[b]{2}{*}{ Parents } & \multicolumn{3}{|c|}{ AF-NAM } & \multicolumn{3}{|c|}{ AM-NAF } \\
\hline & Father & Mother & $\begin{array}{l}\text { Both of Father } \\
\text { \& Mother }\end{array}$ & Father & Mother & $\begin{array}{l}\text { Both of Father } \\
\text { \& Mother }\end{array}$ \\
\hline Percentage & $25 \%$ & - & $10 \%$ & - & $20 \%$ & - \\
\hline
\end{tabular}

Note: AF-NAM: Acehnese Father with Non-Acehnese Mother

AM-NAF: Acehnese Mother with Non-Acehnese father

R3: Ada yang bilang, itu panggilnya Abua, itu panggil nya pakcik (someone told me, to call Abua, to call pakcik)

: Abi kak (father)

R8: Pertama-tama dari saudara abang sepupu, kakak sepupu, terus, emmmm... Ayah pun nyuruh panggelnya Yahwa (first, I heard from my cousin, then, emmmm my father asks me to call Yahwa)

R1: memang dah dari kecil, memang kek gitu dah dari dulu kayak gitu, Ayah yang ajarin (since I was a kid, I was taught by father)

R7: saudara mamak dari mamak bilang, saudara Ayah dari Ayah (to mother's relatives are told by mother, and to father relatives are told by father)

R9: Bapak yang nyuruh.... kakak ayah bilangnya nyakwa ya..,kalau abang Ayah panggel Abua (I was asked by father, the elder sister of father is called nyakwa and the elder brother of father is called $A b u a$ ).

There were $10 \%$ of children whose Acehnese father and Non-Acehnese mother were influenced by both of Acehnese father and Non-Acehnese mother in maintaining the kinship terms completely and partly. It was shown by two respondents below:

R10: Dua-dua lah kak, ikut tutur Aceh kato mamak (both of father and mother, we follow Acehnese language)

R5: ya.. mamak dari ayah trus mamak kasi tou sama kami (yes...mother knows from father, then mother told to us).

There were $20 \%$ of children whose Acehnese mother and Non-Acehnese father were influenced by Acehnese mother in maintaining the kinship terms in Aceh language. It was shown by four respondents below:

R16: Mamak 
nurul ada miwa, salam dulu (Nurul, this is Miwa,)

R17: mamak yang nyuruh tapi gk dipaksa, Cuma dibilang cara manggilnya aja (mother asked me but not forced, just told to me how to call it)

R19: Nyo paknek keuhnyoe, masak kah hana katuri! salami lee (this is your paknek (grandfather), why you don't know him!)

R20: dari mamak (from mother)

The $15 \%$ of children who were influenced by parents' role and they shift the kinship terms above into the role of parents in Acehnese fathers and the role of parents in Acehnese mothers. The table of percentage of children from AF-NAM and AM-NAF is shown below:

TABLE 4: The role of AF-NAM and AM-NAF in shifting the kinship terms in Aceh language.

\begin{tabular}{|l|c|c|c|}
\hline & \multicolumn{3}{|c|}{ AM-NAF } \\
\hline Parents & Father & Mother & $\begin{array}{c}\text { Both of Father \& } \\
\text { Mother }\end{array}$ \\
\hline Percentage & - & $5 \%$ & $5 \%$
\end{tabular}

From three respondents; R11, R14, R15, who shift the kinship terms, most of them were from Acehnese Mother and Non-Acehnese Father intermarriage couple. From the result of the interview, only two respondents were instructed by their mother to use Indonesia language in addressing their family member, for example:

R11: "mamak sama ayah nyuruh kak" (My Mother and May father asked me)

R14: "gak tou, udah kek itu panggelnya.. emmm...sodara kami kek gitu jugak, ikot sodara kadang ada jugak" (I don't know, that has been common term, emmm... our siblings also have the same kinship term. Maybe I imitate my sibling.)

R15: "iky, salam dulu nah Oom ni adek mamak ini". (Iky.. please give honor to your uncle, he is my young brother)

From the result of the interview, it shows that one of them was influenced by the environment in using kinship terms in Indonesia Language and others were given instruction from their parents.

\section{Conclusions}

It is concluded that Acehnese father is mostly influenced by Aceh language in maintaining kinship terms. Furthermore, several respondents found that Acehnese father 
also influences his wife (mother Non-Acehnese) in educating their children at home to use Aceh kinship terms to father Acehnese relatives.

In this study, each child learns from parents or family habitual action. The parent's role is not only found in children who maintain the language in completely and partly, but parents also affect the children to shift the language to other vernacular languages and Indonesian language at home as well.

\section{References}

[1] Batibo, Herman. (2005). Language Decline and Death in Africa. Great Britain: the Cromwell Press.

[2] Bodgan \& Biklen. (1992). Qualitative Research for Education. Boston: Allyn and Bacon.

[3] Crystal, D. (2003). Language Death. Cambridge: Cambridge University Press.

[4] Fishman, Joshua. (1972). The Relationship between Micro- and macro- Sociolinguistics in the Study of Who Speaks What Language to Whom and When. In J.B. Pride and Janet Holmes (eds). Sociolinguistics: Selected Readings. Hammondsworth: Penguin Books.

[5] Holmes, J. (2001). An Introduction to Sociolinguistics. Second Edition. London: Pearson Education Limited.

[6] Mesthri, R. (1999). Language loyalty. In B. Spolsky. Concise encyclopedia of education Linguistic. Oxford: Pergamon

[7] Miles \& Huberman. (1984). Qualitative Data Analysis. Beverly Hills, California: Sage Publication.

[8] Morgan, Charlie, V. (2009). Intermarriage Across Race and Ethnicity Among Immigrants. Washington: Scholarly Publishing.

[9] Scotton, Carol Myers. (2006). Multiple Voices: An Introduction to Billingualism. Oxford: Blackwell Publishing. 